УДК 331.45

\title{
INTELLECTUALIZATION OF THE INFORMATIONAL AND ANALYTICAL LABOR PROTECTION MANAGEMENT SYSTEM ON THE FOOD ENTERPRISE
}

\author{
O. Yevtushenko
}

National University of Food Technologies

\begin{tabular}{|c|c|}
\hline Key words: & ABSTRACT \\
\hline $\begin{array}{l}\text { Labor protection } \\
\text { Labor safety } \\
\text { Occupational injuries } \\
\text { Management } \\
\text { Food enterprise }\end{array}$ & $\begin{array}{l}\text { The intellectualization of the information and analytical } \\
\text { labor protection management system on the food enterprise } \\
\text { is proposed based on decision support system. The task was } \\
\text { solved by introducing an element of intellectualization, } \\
\text { which includes the model of the intellectual agent, into the }\end{array}$ \\
\hline $\begin{array}{l}\quad \text { Article history: } \\
\text { Received } 16.05 .2018 \\
\text { Received in revised form } \\
04.06 .2018 \\
\text { Accepted } 15.06 .2018\end{array}$ & $\begin{array}{l}\text { informational and analytical labor protection management } \\
\text { system, which is described by the parameters of harmful and } \\
\text { dangerous factors and the use of behavior and decision-ma- } \\
\text { king submodels by officials. The intellectual agent model } \\
\text { allows to take into account the dynamics of changes of the }\end{array}$ \\
\hline $\begin{array}{l}\text { Corresponding author: } \\
\text { O. Yevtushenko } \\
\text { E-mail: } \\
\text { npnuht@ukr.net }\end{array}$ & $\begin{array}{l}\text { vector of the labor safety situation, the change of the vector } \\
\text { of regulatory framework of labor protection and the probabi- } \\
\text { lity of an off-peak situation risk on the food industry enterprise. } \\
\text { The conceptual model of the intellectual information and } \\
\text { analytical labor protection management system of food } \\
\text { industry enterprise is developed based on a decision support } \\
\text { system, which provides information about the current state of } \\
\text { safety on the food industry enterprise, information about } \\
\text { changes in the regulatory framework for occupational safety } \\
\text { and health. In the system of decision support, this information } \\
\text { is analyzed and processed, and alternatives to the set of occu- } \\
\text { pational safety measures are given to the head of the labor } \\
\text { protection department. The head of the labor protection de- } \\
\text { partment provides the heads of the structural divisions on the } \\
\text { food enterprise with the optimal set of measures for further } \\
\text { implementation in the structural unit for ensuring labor safety. }\end{array}$ \\
\hline
\end{tabular}

DOI: $10.24263 / 2225-2924-2018-24-3-13$

\section{ІНТЕЛЕКТУАЛІЗАЦІЯ ІНФОРМАЦІЙНО-АНАЛІТИЧНӦ̈ СИСТЕМИ УПРАВЛІННЯ ОХОРОНОЮ ПРАЦІ НА ХАРЧОВОМУ ПІДПРИЕМСТВІ}

\author{
О.В. Свтушенко \\ Національний університет харчових технологій
}

У статті запропоновано інтелектуалізацію інформаційно-аналітичної системи управління охороною пращі харчового підприємства на основі системи 
підтримки прийняття рішень. Поставлене завдання вирішене иляхом впровадження в інтелектуальну інформаційно-аналітичну систему управління охороною праці елемента інтелектуалізації, в яку входить модель інтелектуального агента, щзо описується параметрами шкідливих $і$ небезпечних факторів і використанням субмоделі поведінки та прийняття рішення посадовими особами. Модель інтелектуального агента дає змогу враховувати динаміку зміни вектора стану безпеки праці, зміну вектора нормативноправової бази з охорони прачі та ймовірності ризику настання нештатної ситуачиї на підприємстві харчової промисловості.

Розроблена концептуальна модель інтелектуальної інформаційно-аналітичної системи управління охороною прачі підприємства харчової промисловості, в основі якої міститься система підтримки прийняття рішень, на яку надходить інформація про поточний стан безпеки на харчовому підприємстві, інформачія про зміни в нормативно-правовій базі з охорони праці. В системі підтримки прийняття рішень аналізується та обробляється інформація та надається начальнику служби охорони праці альтернативні варіанти щуодо сукупності заходів з охорони прачі. Начальник служби (відділу) охорони праці надає керівникам структурних підрозділів харчового підприємства оптимальну сукупність заходів до впровадження у структурному підрозділі із забезпечення безпеки прачі в рамках загальної множини нормативно-правової бази з охорони праці.

Ключові слова: охорона прачі, безпека праці, виробничий травматизм, управління охороною прачі, харчове підприємство.

Постановка проблеми. Система управління охороною праці (СУОП) на підприємстві харчової промисловості є базовою основою у забезпеченні безпеки праці на виробництві [1]. Саме рівень СУОП як складова загальної системи управління харчовим підприємством визначає успішність і безпечність виробничих процесів. При аналізі ефективності функціонування СУОП на підприємствах харчової промисловості одним із показників їі функціонування $\epsilon$ рівень нещасних випадків і професійних захворювань. Незважаючи на загальну тенденцію зниження кількості нещасних випадків на підприємствах харчової промисловості, рівень виробничого травматизму залишається високим, темпи його зниження низькими [2]. На основі аналізу статистичних даних і дослідження виробничого травматизму в харчовій промисловості за тривалий період встановлено, що організаційні фактори призводять до $80 \%$ виробничих травм, більшість нещасних випадків відбувається в результаті невірних дій (рішень) або ж порушення вимог нормативно-технічних документів як самими постраждалими, так і іншими працівниками, або їх ігнорування, а також невміння успішно застосовувати необхідні знання у конкретній, особливо у нештатній ситуації з боку керівників структурних підрозділів харчових підприємств [2; 11].

Законодавством України 3 охорони праці передбачений такий розподіл обов'язків з управління охороною праці на будь-якому підприємстві: управління охороною праці на підприємстві здійснює в цілому по підприємству 
директор (роботодавець) і його заступники; у підрозділах - їхні керівники; організаційно-методичну та наглядову діяльність 3 охорони праці, підготовку управлінських рішень і контроль за їх виконанням здійснює служба охорони праці, яка підпорядковується безпосередньо директору [3; 8].

Під час виконання повсякденних операцій фахівцями служб (відділів) охорони праці харчових підприємств обробляються, систематизуються, зберігаються великі обсяги інформації. Але, на жаль, як засвідчує практика, не приділяється належна увага застосуванню накопичених даних для аналізу прийняття рішень й оперативного управління [4]. Залишаються невирішеними питання структуризації даних, розміщених за категоріями (виробничі фактори і умови праці, інструкції, приписи тощо) і вибору цінної інформації.

Проблема полягає перш за все в тому, що доводиться аналізувати і прогнозувати виробничі ситуації з охорони праці. Це значні обсяги інформації, аналіз яких провести своєчасно без сучасних інформаційних технологій (IT) неможливо. Інформаційні технології - невід'ємна частина нашої сучасності, зокрема іiї головна складова за високого рівня розвитку впровадження у наше життя нового стилю керування. Розподіл інформації та побудова інформаційного забезпечення управління охороною праці в більшості своїй характеризує мистецтво керування. Впровадження нових моделей і принципів в інформаційному забезпеченні охорони праці на харчовому підприємстві із залученням сучасних інформаційних технологій відіграє вирішальну роль в обгрунтованості та своєчасності прийнятих управлінських рішень на основі моніторингу умов праці, статистики профзахворювань і травматизму, аналізу виробничих ризиків та ефективності заходів з їх контролю й зниження.

Тож сучасна інформаційно-аналітична система управління охороною праці на харчовому підприємстві повинна бути організована з урахуванням чіткої взаємодії начальника служби (відділу) охорони праці з керівниками всіх структурних підрозділів харчового підприємства, для адекватного та постійного управління з урахуванням усіх факторів, що впливають на стан охорони праці, і надавати керівникам структурних підрозділів оптимальну сукупність заходів забезпечення безпеки праці.

Одним із перспективних наукових напрямків $є$ інтелектуалізація процесу прийняття рішення на основі всього об'єму інформації з охорони праці на харчовому підприємстві. Лише таке прийняття рішень дасть змогу виробити оптимальну сукупність заходів забезпечення охорони праці.

Актуальність роботи підтверджується Загальнодержавною соціальною програмою поліпшення стану безпеки, гігієни праці та виробничого середовища на 2014-2018 роки, затвердженої Законом України від 4 квітня 2013 року № 178-IV.

Аналіз останніх досліджень і публікацій. На підставі проведеного аналізу інформаційно-аналітичних систем, що застосовувались у сфері охорони праці, залежно від мети їх функціонування, вирішуваних завдань, особливостей збору й обробки даних, можна виділити інформаційно-довідкові, інформаційно-розрахункові, інформаційно-керуючі та інтелектуальні інформаційно-аналітичні системи [5]. 
Інформаційно-довідкові системи призначені для занесення в бази даних, збереження, систематизації та видачі за запитом користувача потрібної інформації. Найбільшого розповсюдження у сфері охорони праці набули тематичні інформаційні системи, призначені для зберігання й обробки інформації з різноманітних питань (нормативно-правові та науково-технічні документи, засоби індивідуального та колективного захисту працюючих тощо). Використання таких систем сприяло підвищенню рівня поінформованості фахівців, давало змогу оперативно отримувати необхідні дані та використовувати їх в роботі [5].

Інформаційно-розрахункові системи призначені для проведення в автоматизованому режимі розрахунків відповідно до реалізованих в них алгоритмів. Такі системи широко використовувались для обчислення різноманітних коефіцієнтів та показників стану охорони праці з подальшим збереженням результатів розрахунків у базах даних для їх використання при формуванні звітних і довідкових документів [6].

Слід відзначити, що найбільшого розповсюдження набули інформаційноаналітичні системи, які поєднували в собі риси розрахункових і пошукових систем [6].

Інформаційно-керуючі системи призначені для збору та аналізу даних про параметри технологічного процесу виробничого середовища, для видачі управлінського сигналу (команди) [5; 6].

Інтелектуальні інформаційні системи використовують математичний апарат штучного інтелекту, методи моделювання та прогнозування, експертні, теорії прийняття рішень тощо. Математичний апарат штучного інтелекту є науковою основою створених систем, які імітують розв'язування людиною складаних творчих завдань [7]. До інтелектуальних інформаційних систем (IIAC) можна віднести інформаційно-аналітичні системи, призначені для підтримки управлінських рішень, що виробляються на основі обробки інформації математичними методами. Інтерес до IIAC, як перспективного напрямку використання комп'ютерної техніки та математичного апарату для підвищення ефективності управлінської діяльності, постійно зростає [4; 6]. Застосування IIAC забезпечує вирішення завдань управління, які важко формалізувати, дає змогу об'єктивно оцінити альтернативні варіанти управлінських рішень, проаналізувати можливі результати їж реалізації, обгрунтовано обрати оптимальне рішення. Тобто аналіз результатів вирішення задач, отриманих шляхом комп'ютерного моделювання, надає можливість уникнути можливих помилок у процесі здійснення управлінської діяльності в реальності [6].

Питань підвищення ефективності функціонування системи управління охороною праці, впровадження інформаційних технологій на підприємствах розглянуті в працях: А.О. Водяника, Г.Г. Гогіташвілі, О.І. Запорожця, В.Г. Здановського, О.С. Кружилка, О.О. Лапшина, О.Г. Левченка, М.О. Лисюка, С.О. Ляшенка, В.В. Майстренка, І.М. Подобеда, С.В. Сукача, К.Н. Ткачука та інших.

Аналіз існуючих інформаційно-аналітичних систем у сфері охорони праці свідчить, що накопичено позитивний досвід їх використання для вирішення 
завдань адміністративного моніторингу показників травматизму тощо. Незважаючи на значні переваги, які надає використання інформаційно-аналітичних систем, слід відзначити певну їх обмеженість. Традиційно в інформаційноаналітичних системах відсутні функції вироблення управлінських рішень. Це призводить до нераціонального використання наявних даних, а в окремих випадках - до прийняття недостатньо обгрунтованих управлінських рішень.

Метою статті $\epsilon$ інтелектуалізація інформаційно-аналітичної системи управління охороною праці харчового підприємства на основі системи підтримки прийняття рішень, що дасть змогу начальнику служби (відділу) охорони праці надавати керівникам структурних підрозділів оптимальні сукупності заходів у рамках загальної множини нормативно-правової бази 3 охорони праці.

Викладення основних результатів дослідження. Провідну роль у процесі вдосконалення системи управління охороною праці на харчовому підприємстві відіграє служба (відділ) охорони праці, однією із функцій якої є забезпечення структурних підрозділів нормативно-правовими актами з охорони праці, що діють у межах підприємства [8].

Дієве управління охороною праці можна здійснювати тільки за наявності повної, своєчасної і вірогідної інформації. Одержати таку інформацію, виявити можливі відхилення від норм безпеки, а також перевірити виконання планів та управлінських рішень можна тільки на підставі регулярного й об'єктивного контролю. Контроль стану охорони праці є найбільш відповідальною та трудомісткою функцією. Фахівці з охорони праці контролюють: дотримання чинного законодавства 3 питань охорони праці; виконання приписів; відповідність нормативним актам про охорону праці машин, механізмів, обладнання, транспортних засобів, технологічних процесів, засобів індивідуального, колективного та протиаварійного захисту працівників; забезпечення працівників засобами індивідуального захисту, лікувально-профілактичним харчуванням, санітарно-побутовими приміщеннями; надання працівникам передбачених законодавством пільг і компенсацій, пов'язаних 3 важкими шкідливими умовами праці; виконання заходів, наказів, розпоряджень 3 питань охорони праці, виконання заходів щодо усунення причин нещасних випадків і аварій, визначених в актах розслідування; своєчасне проведення навчання та інструктажів працівників, атестації та переатестації з питань безпеки праці посадових осіб та осіб, які виконують роботи підвищеної небезпеки, а також дотримання вимог безпеки при виконанні цих робіт. Начальник служби (відділу) охорони праці повинен самостійно приймати рішення щодо забезпечення безпеки праці на основі нормативно-правової бази з охорони праці, організовувати, керувати, координувати та контролювати інших працівників структурних підрозділів харчових підприємств [8].

Комплексне дослідження виробничого травматизму вимагає регулярного й оперативного звернення до інформаційних масивів. Система управління охороною праці ефективна, якщо необхідна інформація представляється фахівцю в той момент, коли він може іiі використовувати 3 найбільшою користю для справи. Система інформаційного забезпечення охорони праці має низку особливостей [5]. 
Динамічність інформаційного забезпечення обумовлюється також постійною зміною структури й обсягу нормативної бази з охорони праці, процесами оновлення і поповнення оперативної інформації про стан охорони праці. Така характерна особливість інформаційного забезпечення, як інерційність, обумовлена специфічними особливостями СУОП, які полягають у тому, що відгук системи на багато управляючих дій, наприклад, на впровадження заходів, спрямованих на зниження рівня виробничого травматизму і профзахворювань на об'єктах управління, спостерігається тільки через значні проміжки часу. Однією з відмінних особливостей інформаційного забезпечення СУОП $\epsilon$ одночасна наявність інформації детерміністичного та ймовірнісного характеру [4]. Наявність інформації ймовірнісного характеру обумовлена особливостями СУОП - імовірнісним характером виникнення нещасних випадків $\mathrm{i}$ їх наслідків, впливом суб'єктивного чинника на результати експертних оцінок стану устаткування, машин і механізмів, оцінки умов праці, розслідування нещасних випадків, професійних захворювань, аварій, встановлення ступеня втрати працездатності тощо. Інформація детерміністичного характеру торкається перш за все питань, пов'язаних з урахуванням кадрів, ведення діловодства, ведення реєстру нормативних документів, каталогів засобів захисту тощо. Складність вирішення завдань управління в СУОП обумовлюється також великою періодичністю оновлення значної інформації в системі. Це стосується передусім обліку умов праці, проведеного за результатами атестації робочих місць, та інформації про економічні наслідки травматизму і професійної захворюваності, без урахування якої неможливе планування ефективних заходів з охорони праці [9].

Загальною вимогою при формуванні інформаційних масивів є максимальна формалізація вхідних і вихідних форм подання інформації. Так, наприклад, інформацію про нормативно-правові акти необхідно вносити до бази даних повністю, з урахуванням усіх змін і доповнень. При формуванні цієї бази перевагу слід віддавати тільки офіційним джерелам. Важливою умовою достовірності інформації, яка потрапляє до бази даних, є іiі постійна актуалізація, що вимагає кропіткої та висококваліфікованої роботи фахівця з охорони праці.

При цьому загальною вимогою до інформації будь-якого виду, що потрапляє до бази даних вперше або поновлюється в ній, є необхідність ії датування, оскільки у більшості випадків вона швидко застаріває.

У процесі створення інформаційних масивів вирішуються такі завдання: збирання, систематизація і занесення на машинні носії достовірних даних, які характеризують фактичний стан рівня безпеки трудового процесу й ефективність управління цим процесом; оцінка відхилень фактичного стану охорони праці від вимог, встановлених нормативними й інструктивними документами.

За умови чіткої організації інформаційної бази у розпорядженні начальника служби (відділу) охорони праці харчового підприємства знаходиться максимально можливий набір даних, необхідних для підготовки управлінських рішень, обгрунтованих нормативною інформацією 3 охорони праці (нормами, правилами, інструкціями, стандартами тощо), та надання оптимальної сукупності заходів з охорони праці керівникам структурних підрозділів в 
обсязі, необхідному для забезпечення безпеки праці виробничого персоналу певного структурного підрозділу на підприємстві харчової промисловості.

Тому інтелектуальна інформаційно-аналітична система харчового підприємства має забезпечити підвищення ефективності та досягнення якісно нового рівня прийняття рішень у системі охорони праці, істотно розвинути та зміцнити інформаційно-технічний потенціал, сприяти оперативності, достовірності, доступності та здатна обробляти потік неструктурованих даних, що безперервно зростає.

На сьогодні на сучасних підприємствах харчової промисловості функціонує інформаційно-аналітична система управління охороною праці (IA CУOП) (рис. 1). За допомогою такої системи начальник служби охорони праці спілкується з керівниками структурних підрозділів харчового підприємства.

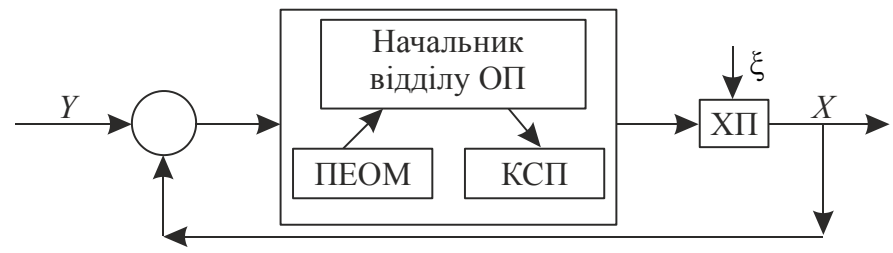

Рис. 1. Модель інформаційно-аналітичної системи управління охороною праці підприємств харчової промисловості

На рис. 1 позначено: $Y$ - вектор вимог нормативно-правової бази; Начальник відділу ОП - начальник служби (відділу) охорони праці підприємства харчової промисловості; ПЕОМ - персональні електронно-обчислювальні машини; КСП - керівники структурних підрозділів харчових підприємств (головний механік, головний енергетик, головний технолог (начальник технологічного відділу); начальник відділу матеріально-технічного постачання; головний бухгалтер; начальник відділу кадрів; начальник відділу капітального будівництва; начальник транспортного підрозділу; начальник господарського відділу та ін.); ХП - харчове підприємство; $\xi$ - дестабілізуючі фактори; $X$ вектор стану безпеки праці на підприємстві харчової промисловості.

Інформаційно-аналітична система управління охороною праці на сучасному харчовому підприємстві спрямована на: збір відомостей про фактичні значення рівнів небезпечних і шкідливих виробничих факторів, показників ризику і безпеки трудових процесів на ділянках і робочих місцях; порівняння цих факторів з установленими нормованими значеннями; визначення величини й аналіз причин відхилення фактичних значень від нормованих; прийняття, організаційних, технічних, оперативних і перспективних рішень (управлінських рішень), спрямованих на ліквідацію відхилень фактичних значень. Розподіл функцій управління між підрозділами підприємства є специфічним для кожного конкретного підприємства харчової галузі і залежить від масштабів, характеру виробництва, складу підрозділів і інших особливостей.

Сучасні інформаційно-аналітичні системи повинні бути орієнтовані на підтримку управлінської діяльності [6]. Створення таких систем передбачає застосування методів теорії прийняття рішень, методів математичного моделювання та прогнозування, теорії прийняття рішень та експертних оцінок [7]. 
Основною задачею, яку повинні вирішувати сучасні IIAC, $\epsilon$ перетворення накопичених даних про стан об'єкта управління охороною праці (діяльність функціональних служб і структурних підрозділів по забезпеченню безпечних i здорових умов праці на робочих місцях, виробничих ділянках, у цехах i харчовому підприємстві в цілому) у форму, яка дає змогу керівнику (начальнику відділу охорони праці) адекватно оцінити стан об'єкта управління охороною праці, оцінити розвиток ситуації та прийняти обгрунтоване управлінське рішення. Тобто відомому стану об'єкта управління охороною праці необхідно поставити у відповідність таку стратегію управління, яка є фізичною реалізацією управлінського рішення, 3 множини припустимих. При цьому обране рішення є оптимальним на підставі визначеного переліку критеріїв прийняття рішень та обмежень [10].

У статті пропонується ввести елемент інтелектуалізації у вигляді системи підтримки прийняття рішень (СППР) в інформаційно-аналітичну систему управління охороною праці, яка нині функціонує на сучасних підприємствах харчової промисловості. Інтелектуальні інформаційно-аналітичні системи (IIAC) можуть застосовуватись для підвищення рівня безпеки праці на підприємствах харчової промисловості [11]. Інтелектуальні інформаційноаналітичні системи, що мають у своїй основі системи підтримки прийняття рішень, на яку поступає інформація про поточний стан безпеки праці на харчовому підприємстві, (статистика травмування та професійних захворювань, тривалість днів непрацездатності працівників, показник ризику настання нештатної ситуаціі), інформація про зміни в нормативно-правовій базі в рамках охорони праці на підприємстві. В системі підтримки прийняття рішень аналізується й обробляється інформація та видаються особі, що приймає рішення, (начальнику служби (відділу) охорони праці), альтернативні варіанти щодо сукупності заходів забезпечення безпеки праці. Начальник служби (відділу) охорони праці на свій експертний розсуд обирає один із варіантів сукупності заходів і надає керівникам структурних підрозділів харчового підприємства оптимальну сукупність заходів до впровадження у структурному підрозділі із забезпечення безпеки праці. Після цього інформація про ризик настання нештатної ситуації та стан безпеки праці перераховується й оновлюється і процес повторюється знову.

У загальному випадку модель інтелектуальної інформаційно-аналітичної системи підприємства харчової промисловості можна подати у такому вигляді (рис. 2).

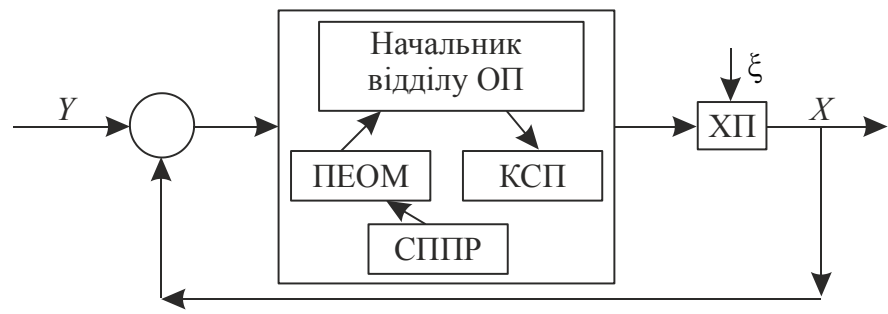

Рис. 2. Модель інтелектуальної інформаційно-аналітичної системи управління охороною праці підприсмства харчової промисловості 
На рис. 2 позначено: $Y$ - вектор нормативно-правової бази; Начальник відділу ОП - начальник служби (відділу) охорони праці підприємства харчової промисловості; ПЕОМ - персональні електронно-обчислювальні машини; СППР - система підтримки прийняття рішень; КСП - керівники структурних підрозділів харчових підприємств (головний механік; головний енергетик; головний технолог (начальник технологічного відділу); начальник відділу матеріально-технічного постачання; головний бухгалтер; начальник відділу кадрів; начальник відділу капітального будівництва; начальник транспортного підрозділу; начальник господарського відділу та ін.); ХП — харчове підприємство; $\xi$ - дестабілізуючі фактори; $X$ - вектор стану безпеки праці на підприємстві харчової промисловості.

Як метод побудови програмних продуктів для інтелектуальної інформаційно-аналітичної системи підприємств харчової промисловості обрано об’єктно-орієнтоване програмування [12].

Необхідним базисом для формалізації інтелектуальних компонентів IAC $€$ модель інформаційного об'єкта (IO), яка повинна будуватися в рамках певної формалізованої системи. Як математичний апарат такої системи доцільно використати логіку першого порядку [12].

Інформаційний об’єкт пропонується визначити таким чином [11]:

$$
O:=\left\langle N_{o},\{A\},\{O\},\{F\},\{N\}\right\rangle,
$$

де $N_{o}$ - ім'я об'єкта; $\{A\}$ - множина атрибутів об'єкта $\left(A_{0}, \ldots, A_{n}\right)$, де $A_{\mathrm{i}}-$ $i$-й атрибут інформаційного об'єкта; $\{O\}-$ множина об'єктів, які структурно входять до даного об'єкта, $\left(O_{\mathrm{NO}_{1}}, O_{\mathrm{NO}_{2}}, \ldots, O_{\mathrm{NO}_{m}}\right)$, де $O_{\mathrm{NO}}-i$-й підпорядкований об'єкт з ім'ям $N_{o}$; $\{F\}$ - множина функцій, які виконує інформаційний об'єкт; $\{N\}$ - множина нормативно-правових актів з охорони праці, в якій відображаються всі вимоги з охорони праці, що впливають на формування сукупності заходів для забезпечення безпеки праці на харчовому підприємстві.

Інтелектуальний агент (IA) - це програмний або апаратний об'єкт, що автономно функціонує для досягнення цілей, поставлених перед користувачем (начальником служби (відділу) охорони праці), володіє певними інтелектуальними здібностями.

На підставі аналізу характеристик і недоліків відомих моделей інтелектуальних агентів (IA) пропонується визначати IA [13] як таку структуру: $\mathrm{IA}=<\mathrm{N}_{\mathrm{IA}}, \mathrm{S}_{\mathrm{A}}, \mathrm{V}_{\mathrm{IA}}, \mathrm{M}_{\mathrm{VB}}, \mathrm{V}_{\mathrm{O}}>$, де $\mathrm{N}_{\mathrm{IA}}-$ ім'я інтелектуального агента; $\mathrm{S}_{\mathrm{A}}-$ структура атрибутів, яка визначається аналогічно структурі атрибутів для інформаційних об'єктів (IO); $\mathrm{V}_{\mathrm{IA}}=\{\mathrm{IA}\}-$ множина вкладених IA; $\mathrm{M}_{\mathrm{VB}}-$ механізм вибору моделі функціонування з урахуванням фактичного стану безпеки праці харчового підприємства; $\mathrm{VO}=\{\mathrm{O}\}-$ множина інформаційних об’єктів, що реалізовують сценарії роботи IА.

Інтелектуальний агент на підставі критеріїв вибору моделі функціонування, закладених в $\mathrm{M}_{\mathrm{VB}}$, приймає рішення про реалізацію в момент часу 
певного сценарію роботи та ініціалізує відповідний IО. Інформаційний простір інтелектуального агента визначається як сукупність IO та IA, що оточують $\mathrm{IA}_{i}$ і взаємодіють 3 ним:

$$
V_{I A_{i}}=\left(A R_{I A}^{i}, A R_{I O}^{i}\right),
$$

де $A R_{I A}^{i}=\left(N_{I A j}, A_{I A_{j}}^{\xi}, \ldots, A_{I A_{j}}^{\psi}, N_{I A I}, A_{I A_{I}}^{\xi}, \ldots, A_{I A_{I}}^{\psi}\right), A R_{I O}^{i}=\left(N_{I O j}, A_{I O_{j}}^{\xi}, \ldots, A_{I O_{j}}^{\psi}, N_{I O I}\right.$, $\left.A_{I I_{I}}^{\xi}, \ldots, A_{I I_{I}}^{\psi}\right)$.

Модель вибору поведінки IA може бути подано:

$$
\mathrm{M}_{\mathrm{VB}}=(\mathrm{MIS}, \mathrm{MG}, \mathrm{MSR}, \mathrm{MA}) \text {, }
$$

де MIS - модель інформаційного середовища; MG - модель цілевизначення; MSR — модель пошуку рішення; MA — модель активних дій.

Модель цілевизначення [13] будується таким чином:

$$
M G_{I A_{i}}=\left(S S_{I A_{i}}, F S S_{I A_{i}}, G S_{I A_{i}}, G_{I A_{i}}^{\text {top }}, G_{I A_{i}}^{\text {down }}, F G_{I A_{i}}^{D}, F G_{I A_{i}}^{S}, F A G_{I A_{i}}, S M A_{I A_{i}}(t)\right)
$$

де $S S$ - множина стратегій, що розуміються як методи вибору цілей $S S=\left(S_{i} \mid i=1, \ldots, n\right) ; F S S$ - функція вибору стратегії; $G S$ - множина статичних цілей; $G^{\text {top }}$ - множина цілей, що отримуються даним IA від агентів більш високого рівня ієрархії; $G^{\text {down }}$ - множина цілей, які можуть бути передані IA нижніх рівнів; $F G^{D}-$ функція формування динамічних цілей; $F G^{S}-$ функція вибору статичних цілей; $F A G-$ функція вибору активних цілей, тобто цілей, прийнятих до реалізації; $S M A$ - стан навколишнього мультиагентного оточення.

Під пошуком рішення слід розуміти знаходження шляху досягнення мети або цілей даним IA в поточному стані мультиагентого оточення. Оскільки різні структурні підрозділи підприємств харчової промисловості володіють своєю специфікою, в тому числі і при прийнятті рішень, то навряд чи $\epsilon$ можливим застосування універсального методу пошуку рішення для всіх підсистем IIAC. Алгоритм пошуку рішення за допомогою інтелектуального агента наведений в [11].

Основою для аналізу і розробки моделей баз знань в IIA СУОП є логічна структура [13]. Логічна структура IIA СУОП повинна розглядатися як структура ієрархічна, з точним визначенням рівнів і підлеглості інтелектуальних компонентів системи.

Це положення обумовлюється тим, що структури організаційного управління охороною праці на підприємствах харчової промисловості мають складну ієрархію (керівник (начальник служби (відділу) охорони праці) - структурні підрозділи тощо), що визначає адміністративні, виробничо-технічні і економічні зв'язки в проектованій системі. При цьому, як правило, спостерігається сувора підлеглість адміністративно-структурних одиниць вищим рівням управління.

Традиційно під базою знань (БЗ) розуміється ядро експертної системи, сукупність знань наочної області, записана на машинний носій у формі, зро- 
зумілій експертові і користувачеві. При розробці структури БЗ для інтелектуальної інформаційно-аналітичної системи управління охороною праці підприємства харчової проомисловості необхідно виходити із структури $\mathrm{i}$ характеру тієї інформації, яку БЗ повинна містити, а це нормативно-правова база з охорони праці.

Базу знань інтелектуального компонента (ІК) можна представити у вигляді такої конструкції:

$$
53_{I K i}=\left(\text { ДДi, } M_{I A}, M_{I O}, Б 3_{\Phi О C}\right),
$$

де ДД $\mathrm{i},-$ дерево декомпозиції інтелектуального компонента $\mathrm{IK}_{\mathrm{i}}, \mathrm{M}_{\mathrm{IA}}$ сукупність моделей IA, пов'язаних 3 даним IK; $\mathrm{M}_{\mathrm{IO}}-$ сукупність моделей

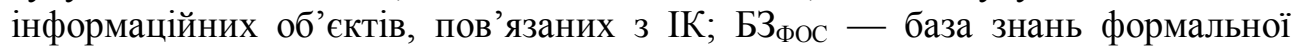
об'єктної системи IК.

Для IIAC СУОП пошук таких формул цілком можливий, оскільки бази знань ІК зберігають знання певного рівня ієрархії і нові знання (в цьому випадку складна цільова формула $Q$ ) можуть виникати в процесі сумісного виводу по декількох Б3 різних ІК [11].

У сучасних системах оперативного управління охороною праці передбачається створення математичного та програмного забезпечення систем прийняття рішень і баз даних; порядок збору, обробки, аналізу та використання даних у процесі здійснення управлінської діяльності [4; 14]. Орієнтація на застосування мережевих технологій є однією з умов ефективного функціонування та розвитку систем оперативного управління охороною праці харчового підприємства.

Об'єктно-орієнтована термінологія визначає об'єкт як пакет, що містить дані, процедури та методи, які надаються як сервіси іншим об'єктам. Абстракція об'єктів багато в чому направлена на ефективне виконання розподілених обчислень, які в об'єктно-орієнтованій системі тісно пов'язані з обміном повідомленнями між об'єктами. Інтелектуальний агент на підставі критеріїв вибору моделі функціонування, закладених у $\mathrm{M}_{\mathrm{VB}}$, приймає рішення про реалізацію в певний момент часу деякого сценарію роботи та ініціалізує відповідний інформаційний об'єкт.

На основі узагальненої моделі IA на базі однієї і тієї ж IIA СУОП можна досліджувати й створювати різноманітні системи, які включають IA.

Ефективність будь-якої системи управління виражається в результативності функціонування об’єкта управління. При аналізі ефективності СУОП харчової промисловості показниками їі функціонування $\epsilon$ ефективне використання системи підтримки прийняття рішень, що враховує вимоги нормативно-правової бази з охорони праці та параметри шкідливих і небезпечних факторів на робочих місцях працівників харчового підприємства. Таке поєднання дає змогу оцінити стан безпеки праці і є підставою для розробки заходів щодо покращення умов праці та запобігання виробничого травматизму.

Для ефективної роботи інтелектуальної інформаційно-аналітичної системи вирішальне значення має налагодження своєчасного надходження достовірної інформації про фактичні значення шкідливих і небезпечних факторів, які 
контролюються на робочих місцях. Носіями інформаційної бази, а також первинними документами в системі обліку та аналізу цього стану можуть бути використані дані атестації робочих місць на харчових підприємствах.

Для зберігання документів запропоновано обирати тип XML, який дає можливість використання його універсальну мову запитів до сховищ інформації. Тип XML надає можливість також здійснювати контроль за коректністю даних, що зберігаються в документах, робити перевірки ієрархічних співвідношень усередині документа і встановлювати єдиний стандарт на структуру документів, змістом яких можуть бути різноманітні дані. Це означає, що його можна використовувати при побудові складних інформаційних систем, в яких дуже важливим є питання обміну інформацією між різними додатками, що працюють в одній системі.

Організація системи надходження інформації пристосована до існуючих методів накопичення даних [14] в загальній роботі інтелектуальної інформаційно-аналітичної системи. Вихідні дані одержує начальник служби (відділу) охорони праці харчового підприємства.

Для ефективного розрахунку ризиків, в тому числі нештатної ситуації, була розроблена комп'ютерна програма «Prophylaxis_of_accidents_1.0» [15], призначена для моніторингу, розрахунку кількісних оцінок різновидів ризику травмування, визначення черговості запровадження та вибору варіантів заходів для профілактики нещасних випадків. У програмі передбачено формування й оцінка матриці ризиків на основі чинної класифікації видів подій і причин, що призводять до травмування на виробництві, з форм обов'язкової статистичної звітності № 7-тнв та рекомендації щодо профілактики найбільш значимих причин та різновидів ризику травмування (з урахуванням вимог нормативноправової бази з охорони праці та аналізу літератури) зі смертельним і без смертельного наслідків.

\section{Висновки}

У статті запропоновано інтелектуалізацію інформаційно-аналітичної системи управління охороною праці на підприємствах харчової промисловості за допомогою введення в ії роботу системи підтримки прийняття рішень із інтелектуальними агентами.

Розроблена концептуальна модель побудови інтелектуальної інформаційно-аналітичної системи управління охороною праці підприємства харчової промисловості, яка враховує загальну роль і місце інтелектуальних складових програмного забезпечення, місце підсистем загальної системи управління у IIAC СУОП, порядок розподілу повноважень між елементами системи. Це дасть змогу начальнику служби (відділу) охорони праці харчового підприємства надавати керівникам структурних підрозділів оптимальну сукупність заходів у рамках загальної множини нормативно-правової бази з охорони праці.

Результати досліджень $\epsilon$ внеском у розвиток теоретичних і прикладних основ охорони праці у частині розроблення систем управління та контролю за безпекою робіт і станом охорони праці, зокрема із застосуванням інформаційних систем для підтримки й прийняття рішень з охорони праці. 


\section{Лiтература}

1. Гогіташвілі Г.Г. Управління охороною праці та ризиком за міжнародними стандартами : навч. посіб. / Г.Г. Гогіташвілі, Є.Т. Карчевські, В.М. Лапін. - Київ : Знання, 2007. - $367 \mathrm{c}$.

2. Євтушенко O.B. Динаміка виробничого травматизму в харчовій галузі України / О.В. Свтушенко, А. О. Сірик // Наукові здобутки молоді - вирішенню проблем харчування людства у XXI столітті : матеріали 81 Міжнародної наукової конференції молодих учених, аспірантів і студентів, 23-24 квітня 2015 р. - Київ : НУХТ, 2015. - Ч. 2. - С. 367.

3. Лисюк М.О. Обов'язки посадових осіб підприємства з охорони праці // Справочник кадровика. - 2012. - № 2. - 200 с.

4. Кружсилко О.С. Удосконалення оперативного управління охороною праці / O.Є. Кружилко, В.В. Майстренко, Г.В. Демчук, О.І. Полукаров // Проблеми охорони праці в Україні : збірник наукових праць. - Київ : ДУ ННДІПБОП, 2016. - Вип. 32. - С. 37-42.

5. Ткачук К.Н. Застосування інформаційних систем в галузі охорони праці : наук.метод. посіб / К.Н. Ткачук, О.Є. Кружилко, Н.А. Праховнік. - Київ : Експодата, 2004. $186 \mathrm{c}$.

6. Кружсилко О.С. Перспективи розвитку інформаційно-аналітичної системи Держпраці України / ОЄ. Кружилко, В.В. Майстренко, М.О. Радіонов, О.І. Полукаров // Проблеми охорони праці в Україні : збірник наукових праць. - Київ : ДУ ННДІПБОП, 2015. - Вип. 30. - С. 25-34.

7. Гороховський O.I. Інтелектуальні системи / O.I. Гороховський ; Вінниц. нац. техн. університет. - Вінниця, 2010. - 193 с.

8. Лисюк М.O. Організація роботи служби охорони праці на підприємстві / М.О. Лисюк / Охорона праці і пожежна безпека. — 2018. - Вип. 2. - С. 22-26.

9. Кружилко О.Є. Оцінка ефективності управлінських рішень у сфері охорони праці / О.Є. Кружилко, В.В. Майстренко, О.І. Полукаров, Г.В. Демчук // Проблеми охорони праці в Україні : збірник наукових праць. - Київ : ДУ ННДІПБОП, 2015. - Вип. 29. — С. 3-9.

10. Барабаш O.B. Построение функционально устойчивых распределенных информационных систем / О.В. Барабаш // - Киев : НАОУ, 2004. — 226 с.

11. Сірик А.О. Моделі та методи підвищення рівня безпеки праці в енергетичному господарстві підприємств харчової промисловості : автореф. дис. ... канд. техн. наук : спец. 05.26.01 - охорона праці / А.О. Сірик ; ДУ «Національний науково-дослідний інститут промислової безпеки та охорони праці», — Київ, 2018. - 20 с.

12. Павлов А.А. Информационные технологии и алгоритмизация в управлении / А.А. Павлова, С.Ф. Теленик - Київ : Техника, 2002. - 344 с.

13. Євтушенко О.В. Побудова моделі інтелектуального агента для інформаційнокеруючої системи енергетичного господарства підприємств харчової промисловості / О.В. Свтушенко, А.О. Сірик // Наукові праці Національного університету харчових технологій. - Київ : НУХТ, 2016. - Т. 22, № 5. - С. 113-119.

14. Барабаш O.B. Модель бази знань інтелектуальної системи управління високошвидкісного рухомого об'єкта на основі ії верифікації / О.В. Барабаш, Д.М. Обідін, А.П. Мусієнко // Системи обробки інформації. - Харків: ХУПС, 2014. - № 5 (121). - С. 3 - 6.

15. А. с. Комп’ютерна програма «Prophylaxis_of_accidents_1.0»/O.В. Свтушенко, А.О. Сірик, П.В. Породько ; Державна служба інтелектуальної власності України. № 67153 ; опубл. 11.08.16. 